\title{
Factors influencing consumers' rejection to smartphone transactions in the lodging industry
}

Stephanie Bae and Jun Mo Kwon

School of Hospitality Leadership, East Carolina University, Greenville, North Carolina, USA, and

Alyssa Bosley

Hart School of Hospitality, Sport and Recreation Management, James Madison University, Harrisonburg, Virginia, USA

\begin{abstract}
Purpose - The main purpose of this study is to investigate what affects a customer's decision to use the hotel smartphone applications when he/she makes a room reservation.

Design/methodology/approach - A total of 266 usable data was collected through an online survey. The research model was tested using confirmatory factor analyses and structural equation modeling.

Findings - This study revealed that perceived usefulness, perceived credibility, perceived equipment risk, and perceived change risk affected customers' intention to book a hotel room using hotel smartphone apps. Perceived ease of use did not have a significant effect on behavioral intention.

Originality/value - This study extended TAM and the existing literature of mobile technology in the lodging industry. This article explored both existing variables and new variables in studying customers' intention to use hotel smartphone apps when booking a hotel room.
\end{abstract}

Keywords TAM, Credibility, Hotel, Smartphone app, Change risk, Equipment risk

Paper type Research paper

\section{Introduction}

With 81 per cent of Americans owning a smartphone, mobile technology has had an enormous effect on consumer behaviors (Bilgihan and Yang, 2016; Park and Huang, 2017; Pew Research Center, 2019; Smith, 2017). Mobile application visitors have increased every year, while the number of visitors for regular Internet websites has decreased (Bohannon, 2014; Kwon et al., 2013; Park and Huang, 2017). Most hotel companies offer a smartphone app and mobile hotel booking has emerged as one of the important booking channels in the lodging industry (Ozturk et al., 2016; Smith, 2017). Travelers can search for travel information, book trips, use location-based and support services, and search for information while traveling (Bohannon, 2014; Kwon et al., 2013; Mahatanankoon et al., 2005; Park and Huang, 2017). Mobile technology has reshaped the hotel industry for customers and companies (Bilgihan and Yang, 2016; Park and Huang, 2017).

In 2017, approximately 33 per cent of travelers booked a hotel room using a smartphone; however, only 10 per cent of people used a hotel's smartphone app (Criteo, 2018). Although major hotel companies have offered mobile apps for smartphone users, smartphone bookings by hotel companies' apps (10 per cent) stayed the same as in the past compared to online

(C) Stephanie Bae, Jun Mo Kwon and Alyssa Bosley. Published in International Hospitality Review. Published by Emerald Publishing Limited. This article is published under the Creative Commons Attribution (CCBY 4.0) licence. Anyone may reproduce, distribute, translate and create derivative works of this article (for both commercial and non-commercial purposes), subject to full attribution to the original publication and authors. The full terms of this licence may be seen at http://creativecommons. org/licences/by/4.0/legalcode
Received 24 September 2019 Revised 23 December 2019 Accepted 23 December 2019 
IHR

34,1

travel agencies' (OTAs') mobile apps (39 per cent) (Criteo, 2018). Many travelers use smartphones as an information searching device (e.g., searching information about amenities at a hotel) and prefer using other devices such as personal computers or laptops to book a hotel room (Anuar et al., 2014; Criteo, 2018; Murphy et al., 2016). In addition, travelers who book a hotel room using a smartphone chose mobile apps offered by online travel agencies (OTAs) instead of using ones from hotel companies (Criteo, 2018). Compared to OTAs' smartphone apps, smartphone apps from hotel companies did not lead smartphone users to actual purchases, which might indicate travelers switch between devices when they plan or book a trip.

Although the percentage of smartphone owners has increased every year, some users consider the smartphone as only an information-searching device instead of a buying device (Agrebi and Jallais, 2015). Furthermore, many smartphone users who book a hotel room using reservation channels provided by hotel companies, still prefer a personal computer for purchasing a travel-related product (Criteo, 2018). However, there is a cost involved for hotel companies to develop and maintain smartphone apps. Moreover, hotel companies pay commissions when guests book a room using OTAs (Hamblen, 2012; Raab et al., 2018; Toh et al., 2011). Therefore, it is imperative for practitioners in the lodging industry to find out what affects a customer's decision to use the hotel smartphone applications when booking a room.

The purpose of this research study was to examine the factors affecting consumers' behavioral intentions (BIs) to use hotel smartphone apps. The specific objectives of the study were to assess the effects of perceived usefulness (PU), defined as the degree of an individual's belief that using the hotel smartphone apps would increase his/her performance, as well as perceived ease of use (PEOU), defined as the degree to which a user believes that using the hotel smartphone apps would be free of effort; if the technology is easier to use, more people will have a positive attitude toward using it (Davis, 1989). Also discussed in the study is the relationships between perceived credibility $(\mathrm{PC})$, the extent to which an individual believes the use of hotel smartphone apps will not pose any security/privacy threats, perceived change risk (PCR), an individual's psychological resistance when he/she needs to deviate from their routine (Lee et al., 2009; Lean and Yen, 2014: Ram; Ram and Sheth, 1989), and perceived equipment risk (PER) which is referred to as the degree of risk a person believes is involved in using a particular technology (Park et al., 2016) and how the level of risks involved can influence a user. For the purposes of this study, all of the aforementioned factors are described in terms of how they would be applied to users' intentions in booking a hotel room through the use of a smartphone application.

\section{Literature review}

Theoretical background

The technology acceptance model (TAM) was derived from Fishbein and Ajzen's (1977) Theory of Reasoned Action (TRA). Theory of Reasoned Action explains that BI of an individual determines the actual behavior, and the BI is affected by attitude and the subjective norm. While attitude is influenced by beliefs and evaluations, the subjective norm is affected by normative beliefs and motivation to comply (Fishbein and Ajzen, 1977).

TAM was initially proposed by Davis (1989) to study employees' acceptance of information technology; however, it has been applied to research studying consumer behavior. TAM posits that PU and PEOU are two main antecedents, which determine users' attitude toward new technologies. In turn, attitude toward using the technology affects BI to use and actual system use (Davis et al., 1989).

The first antecedent is PU, which is described as the degree of a potential user's belief that using the technology would increase their own performance (Davis, 1989). In contrast, PEOU is referred as the degree to which the prospective user believes that using the new technology 
would be free of effort (Davis, 1989). Users' attitude toward new technologies refers potential users' favorable and unfavorable feelings (Kim, 2016). Behavioral intention is a direct determinant of users' actual usage of new technologies and leads to actual adoptions (Fishbein and Ajzen, 1977).

Both TRA and TAM posit that the actual behavior is determined by BI. TRA proposes that BI is influenced by attitude toward behavior and subjective norm, whereas TAM postulates PU and attitude affect BI. However, the final version of TAM only included PU and PEOU as it is parsimonious. For instance, Meuter et al. (2000) concluded that ease of use and convenience affect customers' satisfaction with the self-service technology. Since then, more studies have been using TAM in studying mobile technology in the lodging industry (Kim and Qu, 2014; Kim, 2016; Kwon et al., 2013; Wang and Wang, 2010). Kwon et al. (2013) adopted TAM to explain customers' intention to download mobile apps, and Kim (2016) extended TAM by examining subjective norm and PC when studying the usage of hotel tablet apps. Kim and Qu (2014) also utilized TAM to study intention toward hotel kiosks usage. Although TAM is considered less general than TRA, TAM has been used extensively in explaining consumer behaviors. Previous studies, especially in the lodging industry, found positive relationships between PEOU and PU and BI. As TAM has been widely utilized to explain IT acceptance, it is used as this study's framework and it has led to the following hypotheses:

H1. Customers who perceive a hotel smartphone app to be easy to use will be more willing to book a hotel room.

H2. Customers who perceive a hotel smartphone app to be useful will be more willing to book a hotel room.

\section{Perceived credibility}

Perceived credibility is referred to the extent which a person believes that the use of hotel mobile apps will not have security, or there will be privacy threats (Luarn and Lin, 2005; Wang et al., 2003). Security is the protection of a user's information and systems from unsanctioned access which might lead to unauthorized use of the personal information (Wang et al., 2003). Privacy is related to handling and protecting data that have been collected from the users (Wang et al., 2003).

Although the development of technology has brought convenience, it also poses threats for privacy and security. Studies indicated that individuals tend to behave based on the perceived sense of security (Hoffman et al., 1999; Jose and Varghese, 2018).

In the lodging industry, customers' personal data, such as credit card information and address, is collected during the room reservation process and check-in. Therefore, precautions should be taken as hotels handle the sensitive information.

As seen in the data breach incidents of Marriott and Hyatt, hotel companies should prevent the security and privacy threats in order to protect customers' data (Kim, 2016). Downloading and using mobile apps from hotel companies could mean guests have the brand loyalty to the hotel companies. If customers lose their information by hacking, it will have a bad influence on brand engagement and commitment (Kim et al., 2012). Previous studies have claimed that consumers would not adopt new technologies such as biometrics, RFID, or mobile technologies, if they are highly concerned about privacy and security threats (Hossain and Prybutok, 2008; Kim, 2016).

Previous studies emphasized the importance of $\mathrm{PC}$ and supported that a level of credibility concerns influences a consumer's intention to use the technology. For instance, Wang et al. (2003) concluded that PC was linked to the BI in using online banking. Luarn and Lin (2005)'s research studying attendees of an exposition found that the $\mathrm{PC}$ affects their intention to use mobile banking apps. 
IHR

34,1

In addition to the antecedents in TAM, customers' intention to use hotel mobile apps can be influenced by privacy and security concerns; thus, the following hypothesis was tested:

H3. Customers who perceive a hotel smartphone app to be credible will be more willing to book a hotel room.

Perceived change risk

The status quo bias theory posits that individuals tend to prefer staying with the current situation, so it is challenging to change their behaviors (Markman, 2014; Samuelson and Zeckhauser, 1988). Perceived change risk refers to the degree of psychological resistance an individual exhibits when he/she faces deviation from established traditions (Lee et al., 2009; Liam and Yen, 2014; Ram, 1989; Ram and Sheth, 1989).

Ram and Sheth (1989) introduced five barriers that individuals experience when adopting innovation: usage barrier, value barrier, risk barrier, tradition barrier, and image barrier. The usage barrier is known as the most common reason for consumers to resist the innovation; this barrier indicates that the innovation is incompatible with a consumer's practices or habits. The value barrier refers to consumers' resistance to innovation unless the performance-to-price value is better in innovation. The risk barrier arises when customers are aware of the potential risks with innovation and attempt to postpone the adoption. The tradition barrier, also refers to PCR, represents an individual's resistance to innovation because a change to his/her established routine is required. Lastly, the image barrier is related to an unfavorable image or the stereotype of a product that discourages consumers to adopt innovation (Ram and Sheth, 1989).

The findings from the studies on information technology support the fact that resistance to change the established tradition affects consumers' intention to use the new technology. For instance, Ram (1989) indicated that an individual would less likely adopt the innovations if they do not fit his/her preferences, for example, established routine. Several studies claimed that a tendency toward an existing practice of an individual affects his/her intention to resist innovation in online banking services (Kuisma et al., 2007; Martins et al., 2014; Sheth, 1981). Considering innovation requires consumers change in their routine, the following hypothesis was proposed:

H4. Customers who are less willing to change their routine will be less willing to book a hotel room using a hotel smartphone app.

\section{Perceived equipment risk}

Perceived equipment risk refers to the degree an individual believes that there is the possibility of loss caused or intercepted by mobile technology (Park et al., 2016). It is related to limitations of smartphone features such as usability and the quality of service (Elias, 2011; Eriksson, 2014; Kargin et al., 2008).

Previous studies support the fact that if a consumer has a high level of equipment risk, it would negatively affect his/her intention to use it (Elias, 2011; Eriksson, 2014; Kargin et al., 2008; Kim and Sundar, 2014). For example, smartphone screen size has been identified to be highly related with smartphone adoption in utilitarian and hedonic purposes; however, the smaller size screen makes it difficult to navigate when individuals are accustomed with a bigger screen on a computer/laptop. Usability is related to sufficient technology, such as the quality of navigation and limitation in relevant services (Eriksson, 2014, Safer, 2014). For example, smartphone users may have a poor experience of browsing mobile websites because they have poor navigation, they are not fast, or designed for a smartphone (Kim and Sundar, 2014; Safer, 2014). In addition, both Aldhaban et al. (2015)'s study and Kim et al. (2015)'s studies claimed that performance of the smartphone affects the BI of customers. The lodging 
industry should focus on these issues as the recent study found the number of customers using the hotel apps are not increasing in spite of hotel companies' efforts (Criteo, 2018). Considering the lack of usability construct in TAM and previous studies, the following hypothesis is proposed:

H5. Customers who perceive a hotel smartphone app as nonsufficient will be less willing to book a hotel room.

Based on the previous studies, we propose the research model in which PU, PEOU, PC, PER, and PCR influence BI toward hotel smartphone apps (see Figure 1).

\section{Methodology}

The survey questions were developed based on a comprehensive review of related literature. Items measuring PU and PEOU were adapted from the work of Davis (1989). Items measuring PC were based on the work of Wang et al. (2003), and the works of Ram and Sheth (1989) and Goldsmith and Hofacker (1991) were used to measure PCR. The PER was measured using items from the works of Kim et al. (2015) and Kim and Sundar (2014). Lastly, BI was measured with items from the work of Venkatesh et al. (2003). All items were revised to accommodate the information technology in the lodging industry, and respondents used a seven-point Likert scale, ranging from (1) "strongly disagree" to (7) "strongly agree" to respond to the questionnaire except for questions asking for socio-demographic information.

To reach the sample, the Qualtrics' panel database was used to collect the national data. An invitation with a link to the survey was sent to the panel to complete the online survey in return for incentives/cash honorarium. The target population for this research were customers who had stayed in a hotel at least once during the last 12 months and had never booked on a hotel smartphone app. Those not meeting the criteria were screened out. A total

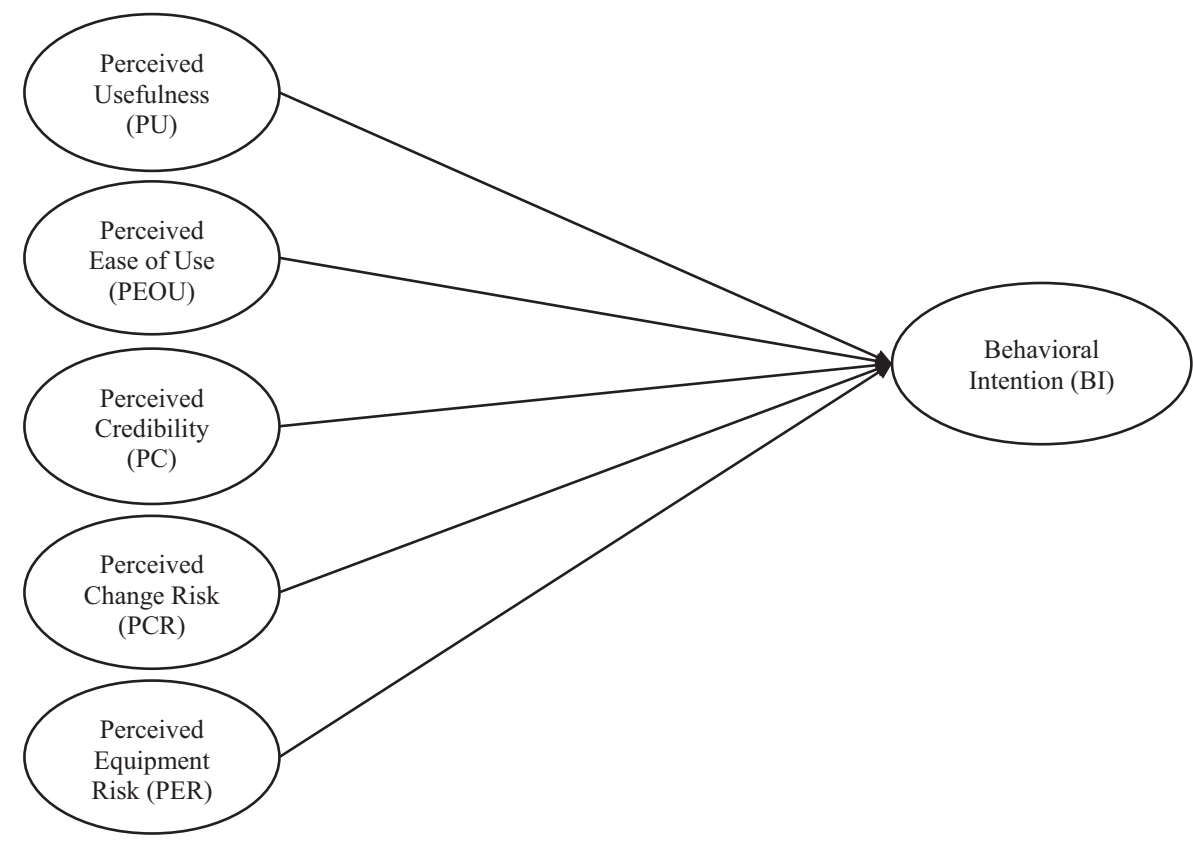

Figure 1. Proposed model 
IHR 34,1

\section{4}

\section{Results}

Characteristics of participants

Of the 266 respondents, approximately 59 per cent of respondents were female and over 68 per cent were at least 40 years old. One third of respondents reported that they contacted the hotel to make a room reservation, whereas about 47 per cent booked a hotel room using their personal computer (see Table I).

\section{Measurement model}

Confirmatory factor analysis (CFA) was conducted using Amos 24. Results of CFA showed that all factor loadings were greater than 0.6, and the measurement model

\begin{tabular}{|c|c|c|c|}
\hline Variables & Item & $N$ & $\%$ \\
\hline \multirow[t]{2}{*}{ Gender } & Male & 109 & 41 \\
\hline & Female & 157 & 59 \\
\hline \multirow[t]{7}{*}{ Age } & $18-20$ years old & 2 & 0.8 \\
\hline & 21-30 years old & 31 & 11.7 \\
\hline & $31-40$ years old & 57 & 21.4 \\
\hline & $41-50$ years old & 49 & 18.4 \\
\hline & $51-60$ years old & 69 & 25.9 \\
\hline & $61-70$ years old & 48 & 18.0 \\
\hline & 71 years old and older & 10 & 3.8 \\
\hline \multirow[t]{6}{*}{ Level of education } & Less than high school & 2 & 0.8 \\
\hline & High school/GED & 61 & 22.9 \\
\hline & Some college & 84 & 31.6 \\
\hline & Two-year college degree & 34 & 12.8 \\
\hline & Four-year college degree & 61 & 22.9 \\
\hline & Master's degree or higher & 24 & 9.0 \\
\hline \multirow[t]{6}{*}{ Annual income } & Below $\$ 20,000$ & 47 & 17.7 \\
\hline & $\$ 20,000-\$ 40,000$ & 72 & 27.1 \\
\hline & $\$ 40,001-\$ 60,000$ & 63 & 23.7 \\
\hline & $\$ 60,001-\$ 80,000$ & 35 & 13.2 \\
\hline & $\$ 80,000-\$ 100,000$ & 27 & 10.2 \\
\hline & $\$ 100,001$ or more & 22 & 8.3 \\
\hline \multirow[t]{6}{*}{ Frequencies of hotel stay } & 1 time & 97 & 36.5 \\
\hline & $2-3$ times & 94 & 35.3 \\
\hline & $4-5$ times & 41 & 15.4 \\
\hline & 6-7 times & 18 & 6.8 \\
\hline & $8-9$ times & 9 & 3.4 \\
\hline & 10 times or more & 7 & 2.6 \\
\hline \multirow[t]{5}{*}{ Booking method } & Call & 88 & 33.1 \\
\hline & Desktop & 69 & 25.9 \\
\hline & Laptop & 67 & 25.2 \\
\hline & Tablet & 3 & 1.1 \\
\hline & Others & 39 & 14.7 \\
\hline \multirow[t]{2}{*}{ Tablet ownership } & Yes & 154 & 57.9 \\
\hline & No & 112 & 42.1 \\
\hline
\end{tabular}

Table I.

Demographic profile $(N=266)$ of three attention check questions were built into the survey to determine whether the respondents read the instructions and answered questions carefully. In addition, all responses A total of 287 participants completed the survey; however, 21 surveys were screened out because they either did not take a trip in the last 12 months or got a wrong answer on attention questions. Therefore, a total of 266 questionnaires were used for data analysis. 
showed an acceptable fit $\chi^{2}(137)=216.3, p<0.001$, CFI $=0.983$, NFI $=0.955$, RMSEA $=0.047$ ). As shown in Table II, the standardized factor loadings were met the minimum criterion of 0.50 (Hair et al., 1998); ranging from 0.73 to 0.98. All measures were evaluated for reliability and convergent and discriminant validity (see Table III). Composite reliability was used to determine reliability of the study, and each construct showed a good item reliability ranging from 0.852 to 0.972 . Convergent validity was assessed by using average variance extracted (AVE), and all values for AVE were greater than 0.5. Discriminant validity was evaluated by comparing the square root of AVE for each construct to correlations with other factors, and this study showed no

Perceived usefulness (PU)

Hotel smartphone applications are useful

Hotel smartphone apps enable me to accomplish tasks quickly

Hotel smartphone apps increase my productivity

0.87

0.86

0.80

Perceived ease of use (PEOU)

Hotel smartphone applications are not complicated $\quad 0.95$

Hotel smartphone applications are easy to use $\quad 0.92$

Hotel smartphone applications are clear

0.76

Perceived credibility $(P C)$

I would find a hotel smartphone app secure in conducting my transactions $\quad 0.89$

Using a hotel smartphone app would not divulge my personal information $\quad 0.88$

I would not lose my personal information in using a hotel smartphone app $\quad 0.84$

Hotel smartphone apps are secure to use

0.78

Perceived change risk (PCR)

I am among the last in my circle of friends to try new things

I will not try anything new if I have to change my established tradition

I do not like to deviate from my routine

0.97

0.92

0.90

Perceived equipment risk (PER)

If I use hotel smartphone apps, they will stop unexpectedly

The hotel smartphone apps do not allow me to be sufficient

0.94

The hotel smartphone apps do not support all the tasks that I need

0.75

0.73

Behavioral intention (BI)

I would use a hotel smartphone app when I book a hotel room

I would use a smartphone transaction via a hotel smartphone app when I book a hotel 0.96 room

I would book a hotel room using a hotel smartphone app
Table II. Measurement model

\begin{tabular}{|c|c|c|c|c|c|c|c|c|c|c|c|}
\hline & $\mathrm{CR}$ & AVE & MSV & ASV & $\mathrm{PU}$ & PEOU & PC & PCR & PER & BI & \\
\hline PU & 0.881 & 0.711 & 0.378 & 0.325 & 0.843 & & & & & & \\
\hline PEOU & 0.911 & 0.774 & 0.510 & 0.299 & 0.582 & 0.880 & & & & & \\
\hline PC & 0.910 & 0.718 & 0.378 & 0.278 & 0.615 & 0.483 & 0.847 & & & & \\
\hline PCR & 0.950 & 0.865 & 0.510 & 0.293 & 0.605 & 0.714 & 0.508 & 0.930 & & & \\
\hline PER & 0.852 & 0.660 & 0.281 & 0.245 & 0.511 & 0.514 & 0.530 & 0.498 & 0.812 & & Table III \\
\hline $\mathrm{BI}$ & 0.972 & 0.919 & 0.281 & 0.185 & 0.530 & 0.385 & 0.488 & 0.292 & 0.416 & 0.959 & Correlations, validity \\
\hline \multicolumn{11}{|c|}{ Note: Square root of AVE for each construct is in italics } & and reliability \\
\hline
\end{tabular}


IHR

34,1

concerns for discriminant validity. All constructs' square root of AVE was greater than correlations with other constructs.

\section{Structural model}

Structural equation modeling (SEM), using Amos 24, was used to test the hypotheses of this research. The result showed a good fit: $\chi^{2}(137)=216.3, \chi^{2} / \mathrm{df}=1.58, p<0.001$, $\mathrm{CFI}=0.983, \mathrm{NFI}=0.955, \mathrm{RMSEA}=0.047$. An examination of path estimates showed that PU $(\beta=0.364, t=4.387, p<0.01)$ and $\mathrm{PC}(\beta=0.230, t=3.044, p<0.01)$ had significant effects on $\mathrm{BI}$, supporting $\mathrm{H} 2$ and H3. In addition, PCR $(\beta=-0.220, t=-2.618$, $p<0.01)$ and PER $(\beta=-0.143, t=-1.994, p<0.05)$ showed significant effects on BI, supporting H4 and H5. However, PEOU did not show a significant effect on BI $(\beta=0.146$, $t=1.726, p>0.05)$; therefore, $\mathrm{H} 1$ was not supported.

\section{Conclusion}

With advancement of mobile technology, customers can book their hotel room using smartphone apps developed by hotel companies. Smartphone transactions have been increasing every year in the hotel industry; however, transactions using hotel smartphone apps is consistently on a low level.

To the authors' knowledge, there is no research focusing on consumer acceptance and avoidance of hotel smartphone apps. Therefore, the antecedents of acceptance of hotel smartphone apps that were tested in this study will shed light on the existing literature of mobile technology in the lodging industry.

This study found that PU had the strongest influence on consumers' intention to use hotel smartphone transactions $(\beta=0.364)$, which is consistent with previous studies (Brown et al., 2002; Kim and Qu, 2014; Kwon et al., 2013). In other words, consumers are more likely to use a hotel smartphone app if they perceive their experience as useful. In addition, $\mathrm{PC}$ was found to have a significant positive effect on BI of using a hotel smartphone app when booking a hotel $\operatorname{room}(\beta=0.230)$. This is also consistent with the previous studies conducted for the banking and hospitality industry (Kim, 2016; Luarn and Lin, 2005; Park et al., 2016; Wang et al., 2003). This indicated that the security and privacy threats should be overcome to increase adoption of hotel smartphone apps.

In addition to PU and PCR, PER was found to be negatively related to BI $(\beta=-0.220)$. The result indicated that consumers who believe a hotel smartphone app is not sufficient will less likely book a hotel room using the app. This is consistent with previous studies (Aldhaban et al., 2015; Elias, 2011; Eriksson, 2014; Kargin et al., 2008; Kim et al., 2015; Park et al., 2016).

Lastly, PCR showed a negative effect on BI $(\beta=-0.143)$. This finding indicated that consumers who resist changing their established routine are less likely to book a hotel room using a hotel smartphone app. This is consistent with previous research. In fact, recent research concluded that most consumers who book a hotel room directly from hotel companies prefer using their personal computers (Criteo, 2018). For them, using a hotel smartphone app to make a room reservation is a deviation from their established routine.

As mentioned earlier, PEOU did not have a significant effect on BI. This result contradicts the findings of past studies. Previous studies conducted for the airline industry had shown that PEOU showed a significant influence on the BI. For instance, both Morosan's (2012) study about biometrics in the airports and Morosan's (2014) study focusing on using mobile phones for purchasing in the airplane, showed that PEOU significantly affected the BI. A possible explanation for this study's differing result is that smartphones have been present for nearly 10 years and approximately 81 per cent of Americans own a smartphone. Consumers are accustomed to using their smartphone which means they know how to. 
Another possible reason could be the differences between the airline and lodging industries and each of its customers.

This study tested and extended the original TAM in the use of hotel smartphone apps. Previous research had focused on the constructs from the original TAM (e.g., PU and PEOU). However, as technology advances, interests on predictive variables has increased. This study contributes to the TAM by adding PC, PCR, and PER to further explain the acceptance behaviors.

From a practical perspective, hotel owners and operators could provide incentives if customers book using the hotel's smartphone app. For example, hotels can offer a discount or an upgrade on room reservations made through their smartphone app. This could allow customers who would not normally deviate from their routine to be motivated to use the hotel smartphone app. Additionally, to reach more consumers, a pop-up screen or a notice can be posted on the hotel's official website to inform about the hotel smartphone apps and the incentives.

Results indicate hotel owners and operators should update their apps to ensure it is compatible with platforms such as Google Android or Apple iOS. For instance, the apps might not move on to the next page or could shut down unexpectedly if not up-to-date. This is problematic, especially if the customer is in the process of making a reservation and their entered data is lost. They would be forced to start over, or they might fear they will be charged more than once. Updated apps can encourage customers to book a hotel room using the company's app.

Hotel owners and operators should enhance their security and any possible threats on their smartphone apps, and make an announcement about their efforts. For example, similar to secure websites viewed on a computer, a logo or signature of mobile security services should be visible on the hotel smartphone apps to increase customer trust. In addition, customers will feel confident about a hotel's smartphone app if the establishment communicates more via emails, text messages, in-room brochures, or signage.

Only about 10 per cent of hotel guests book a hotel room using the apps offered by hotel companies (Criteo, 2018). Many hotel guests who book a room using reservation channels provided by hotel companies still prefer to use a personal computer. The percentage of OTA app users has increased every year because hotel guests who book a hotel room using a smartphone are mostly last- minutes users (Criteo, 2018). OTA apps could provide comparisons of competitors in the same area, but hotel apps could not provide competitors information in their own apps. Therefore, hotel practitioners should emphasize other functions in their apps for their guests to feel smartphone applications from hotel companies are useful. For example, hotel companies can provide early check-ins, room keys, or information about each property (such as location) in their mobile app. By using the hotel smartphone apps, hotel guests can save time and effort by going to the room directly instead of waiting at the front desk for check-in when they arrive at hotels. According to Kim (2016), one of hotel guests' preferred functions in mobile applications was browsing hotel facilities. Hotel guests could not see the hotel facility until they check in, so hotel practitioners could provide three-dimensional (3D) features of facilities in smartphone apps to assist guests in choosing their accommodations.

This study has some limitations that could direct future research. We examined antecedents based on TAM and three additional ones to find out what affects a customer's decision to make a room reservation through the hotel smartphone applications. A future study can investigate other antecedents and expand TAM further to study a customer's purchasing decision to use hotel smartphone apps. This study only focused on smartphone apps from the hotel companies. The results can be expanded to other segments in the hospitality industry such as restaurants, airlines, wine, theme parks, etc. where customers can purchase products and services from their smartphones. 
IHR

34,1

\section{References}

Agrebi, S. and Jallais, J. (2015), "Explain the intention to use smartphones for mobile shopping", Journal of Retailing and Consumer Services, Vol. 22, pp. 16-23.

Aldhaban, F., Daim, T.U. and Harmon, R. (2015), "Exploring the adoption and use of the smartphone technology in emerging regions: a literature review and hypotheses development", in Management of Engineering and Technology (PICMET) 2015, proceedings of International Conference in Portland, United States, IEEE, pp. 2355-2370.

Anuar, J., Musa, M. and Khalid, K. (2014), "Smartphone's application adoption benefits using mobile hotel reservation system (MHRS) among 3-5-star city hotels in Malaysia”, Procedia-Social and Behavioral Sciences, Vol. 130, pp. 552-557.

Bilgihan, A. and Wang, Y. (2016), "Technology induced competitive advantage: a case of US lodging industry", Journal of Hospitality and Tourism Technology, Vol. 7 No. 1, pp. 37-59.

Bohannon, C. (2014), "Mobile shopping officially trumps desktop: report”, Retail Dive, Vol. 9 September, available at: https://www.retaildive.com/ex/mobilecommercedaily/mobile-shoppingofficially-trumps-desktop-report (accessed 5 August 2018).

Brown, S.A., Massey, A.P., Montoya-Weiss, M.M. and Burkman, J.R. (2002), "Do i really have to? User acceptance of mandated technology", European Journal of Information Systems, Vol. 11 No. 4, pp. 283-295.

Criteo (2018), “Travel flash report”, Criteo, available at: https://www.criteo.com/wp-content/uploads/ 2018/01/18_Criteo_Travel_Report.pdf (accessed 5 June 2018).

Davis, F.D. (1989), "Perceived usefulness, perceived ease of use, and user acceptance of information technology”, MIS Quarterly, Vol. 13 No. 3, pp. 319-340.

Davis, F.D., Bagozzi, R.P. and Warshaw, P.R. (1989), "User acceptance of computer technology: a comparison of two theoretical models", Management Science, Vol. 35 No. 8, pp. 982-1003.

Elias, T. (2011), "Universal instructional design principles for mobile learning", The International Review of Research in Open and Distributed Learning, Vol. 2 No. 2, pp. 143-156.

Eriksson, N. (2014), "User categories of mobile travel services", Journal of Hospitality and Tourism Technology, Vol. 5 No. 1, pp. 17-30.

Fishbein, M. and Ajzen, I. (1975), Belief, Attitude, Intention, and Behavior: An Introduction to Theory and Research, Addision-Wesley, Reading, MA.

Goldsmith, R.E. and Hofacker, C.F. (1991), "Measuring consumer innovativeness", Journal of the Academy of Marketing Science, Vol. 19 No. 3, pp. 209-221.

Hair, J.F., Anderson, R.E., Tatham, R.K. and Black, W.C. (1998), Multivariate Data Analysis, Prentice Hall, Upper Saddle River, NJ.

Hamblen, M. (2012), "Chief mobile officer: a job title now timely?: an old idea gets new life as mobile strategies gain importance", Computerworld, available at: http://www.computerworld. com/article/2501477/mobile-apps/chief-mobile-officer-a-job-title-now-timely-html (accessed 3 June 2018).

Hossain, M.M. and Prybutok, V.R. (2008), "Consumer acceptance of RFID technology: an exploratory study”, IEEE Transactions on Engineering Management, Vol. 55 No. 2, pp. 316-328.

Hoffman, D.L., Novak, T.P. and Peralta, M. (1999), "Building consumer trust online", Communications of the ACM', Vol. 42 No. 4, pp. 80-85.

Jose, A., and Varghese, R. (2018), "Consumer adoption of mobile banking in India: examining the role of usefulness, ease of use, perceived risk and trust", International Journal of Research and Analytical Reviews, Vol. 5 No. 4, pp. 97-103.

Kargin, B., Basoglu, N. and Daim, T. (2008), "Factors affecting the adoption of mobile services", International Journal of Services Sciences, Vol. 1, pp. 29-52. 
Kim, J. (2016). "An extended technology acceptance model in behavioral intention toward hotel tablet apps with moderating effects of gender and age", International Journal of Contemporary Hospitality Management, Vol. 28 No. 8, pp. 1535-1553.

Kim, J., Christodoulidou, N. and Brewer, P. (2012), "Impact of individual differences and consumers' readiness on likelihood of using self-service technologies at hospitality settings", Journal of Hospitality and Tourism Research, Vol. 36 No. 1, pp. 85-114.

Kim, K.J. and Sundar, S.S. (2014), "Does screen size matter for smartphones? Utilitarian and hedonic effects of screen size on smartphone adoption", Cyberpsychology, Behavior, and Social Networking, Vol. 17 No. 7, pp. 466-473.

Kim, M. and Qu, H. (2014), "Travelers' behavioral intention toward hotel self-service kiosks usage", International Journal of Contemporary Hospitality Management, Vol. 26 No. 2, pp. 225-245.

Kim, M.K., Chang, Y., Wong, S.F. and Park, M.C. (2015), "The effect of perceived risks and switching barriers on the intention to use smartphones among non-adopters in Korea", Information Development, Vol. 31 No. 3, pp. 258-269.

Kuisma, T., Laukkanen, T. and Hiltunen, M. (2007), "Mapping the reasons for resistance to Internet banking: a means-end approach", International Journal of Information Management, Vol. 27 No. 2, pp. 75-85.

Kwon, J.M., Bae, J.I. and Blum, S.C. (2013), "Mobile applications in the hospitality industry", Journal of Hospitality and Tourism Technology, Vol. 4 No. 1, pp. 81-92.

Lee, J., Morrin, M. and Lee, J. (2009), "Managing adoption barriers in integrated banking services", Journal of Services Marketing, Vol. 23 No. 7, pp. 508-516.

Liam, J. and Yen, D.C. (2014), Online shopping drivers and barriers for older adults: age and gender differences", Computers in Human Behavior, Vol. 37, pp. 133-143.

Luarn, P. and Lin, H.H. (2005), "Toward an understanding of the behavioral intention to use mobile banking", Computers in Human Behavior, Vol. 21 No. 6, pp. 873-891.

Mahatanankoon, P., Wen, H.J. and Lim, B. (2005), "Consumer-based m-commerce: exploring consumer perception of mobile applications", Computer Standards and Interfaces, Vol. 27 No. 4, pp. 347-357.

Markman, G.D. (2014), “Entrepreneurs' competencies”, in Baum, J.R., Frese, M. and Baron, R.A. (Eds), The Psychology of Entrepreneurship, Psychology Press, New York, NY, pp. 99-124.

Martins, C., Oliveira, T. and Popovic, A. (2014), "Understanding the internet banking adoption: a unified theory of acceptance and use of technology and perceived risk application", International Journal of Information Management, Vol. 34 No. 1, pp. 1-13.

Meuter, M.L., Ostrom, A.L., Roundtree, R.I. and Bitner, M.J. (2000), "Self-service technologies: understanding customer satisfaction with technology-based service encounters", Journal of Marketing, Vol. 64 No. 3, pp. 50-64.

Morosan, C. (2012), "Voluntary steps toward air travel security: an examination of travelers' attitudes and intentions to use biometric systems", Journal of Travel Research, Vol. 51 No. 4, pp. 436-450.

Morosan, C. (2014), "Toward an integrated model of adoption of mobile phones for purchasing ancillary services in air travel", International Journal of Contemporary Hospitality Management, Vol. 26 No. 2, pp. 246-271.

Murphy, H.C., Chen, M.M. and Cossutta, M. (2016), "An investigation of multiple devices and information sources used in the hotel booking process", Tourism Management, Vol. 52, pp. 44-51.

Ozturk, A.B., Bilgihan, A., Nusair, K. and Okumus, F. (2016), "What keeps the mobile hotel booking users loyal? Investigating the roles of self-efficacy, compatibility, perceived ease of use, and perceived convenience", International Journal of Information Management, Vol. 36 No. 6, pp. 1350-1359.

Park, S. and Huang, Y. (2017), "Motivators and inhibitors in booking a hotel via smartphones", International Journal of Contemporary Hospitality Management, Vol. 29 No. 1, pp. 161-178. 
IHR

34,1

Park, S., Tussyadiah, I.P. and Zhang, Y. (2016), "Assessment of perceived risk in mobile travel booking", in Information and Communication Technologies in Tourism 2016 Proceedings of International Conference in Bilbao, Spain, 2016, Springer, Cham, pp. 467-480.

Pew Research Center (2019), Mobile Fact Sheet, available at https://www.pewresearch.org/internet/ fact-sheet/mobile/.

Raab, C., Berezan, O., Christodoulidou, N., Jiang, L. and Shoemaker, S. (2018), "Creating strategic relationships with online travel agents to drive hotel room revenue: an OTA perspective", Journal of Hospitality and Tourism Technology, Vol. 9 No. 1, pp. 125-140.

Ram, S. (1989), "Successful innovation using strategies to reduce consumer resistance an empirical test", Journal of Product Innovation Management: An International Publication of the Product Development and Management Association, Vol. 6 No. 1, pp. 20-34.

Ram, S. and Sheth, J.N. (1989), "Consumer resistance to innovations: the marketing problem and its solutions", Journal of Consumer Marketing, Vol. 6 No. 2, pp. 5-14.

Sheth, J.N. (1981), "Psychology of innovation resistance: the less developed concept (LDC) in diffusion research", Research in Marketing, Vol. 4 No. 3, pp. 273-282.

Safer, M.M. (2014), “Why aren't there more mobile hotel website bookings?”, Hotel Business Review, available at: http://hotelexecutive.com/business_review/3747/why-arent-there-more-mobilehotel-website-bookings (accessed 16 May 2018).

Samuelson, W. and Zeckhauser, R. (1988), "Status quo bias in decision making", Journal of Risk and Uncertainty, Vol. 1 No. 1, pp. 7-59.

Smith, A. (2017), "Record shares of Americans now own smartphones, have home broadband", available at: https://www.pewresearch.org/fact-tank/2017/01/12/evolution-of-technology/.

Toh, R.S., Raven, P. and DeKay, F. (2011), "Selling rooms: hotels vs. third-party websites", Cornell Hospitality Quarterly, Vol. 52 No. 2, pp. 181-189.

Venkatesh, V., Morris, M.G., Davis, G.B. and Davis, F.D. (2003), "User acceptance of information technology: toward a unified view", MIS Quarterly, Vol. 27 No. 3, pp. 425-478.

Wang, H.Y. and Wang, S.H. (2010), "Predicting mobile hotel reservation adoption: insight from a perceived value standpoint", International Journal of Hospitality Management, Vol. 29 No. 4, pp. 598-608.

Wang, Y.S., Wang, Y.M., Lin, H.H. and Tang, T.I. (2003), "Determinants of user acceptance of Internet banking: an empirical study", International Journal of Service Industry Management, Vol. 14 No. 5, pp. 501-519.

\section{Further reading}

Bitner, M.J., Brown, S.W. and Meuter, M.L. (2000), "Technology infusion in service encounters", Journal of the Academy of marketing Science, Vol. 28 No. 1, pp. 138-149.

Chiu, J.L., Bool, N.C. and Chiu, C.L. (2017), "Challenges and factors influencing trust and behavioral intention to use mobile banking services in the Philippines", Asia Pacific Journal of Innovation and Entrepreneurship, Vol. 11 No. 2, pp. 246-278.

Wang, D., Park, S. and Fesenmaier, D.R. (2012), "The role of smartphones in mediating the touristic experience", Journal of Travel Research, Vol. 51 No. 4, pp. 371-387.

\section{Corresponding author}

Stephanie Bae can be contacted at: baej17@ecu.edu

For instructions on how to order reprints of this article, please visit our website:

www.emeraldgrouppublishing.com/licensing/reprints.htm

Or contact us for further details: permissions@emeraldinsight.com 